\title{
STANDAR OPERASIONAL PROSEDUR (SOP) \\ PELAKSANAAN DIVERSI OLEH PENUNTUT UMUM ANAK DALAM \\ SISTEM PERADILAN PIDANA ANAK
}

\author{
Yulianto $^{1}$, Pujiyono ${ }^{2}$
}

\begin{abstract}
Abstrak
Penanganan perkara anak berhadapan dengan hukum yang mengutamakan kepentingan terbaik bagi anak masih jauh dari yang diharapkan sehingga dikeluarkan Undang-Undang Nomor 11 Tahun 2012 tentang Sistem Peradilan Pidana Anak (SPPA) yang di dalamnya mengatur Diversi dalam Pasal 6 sampai Pasal 16. Diversi didasarkan pada prinsip Restorative Justice yang mengembalikan konflik kepada pihak-pihak yang paling terkena pengaruh anak korban dan anak pelaku tindak pidana. Pentingnya SOP Diversi dalam Penuntutan terhadap Anak Berhadapan dengan Hukum (ABH), diantaranya karena Pasal 7 SPPA mengamanatkan bahwa di setiap proses penyidikan, penuntutan, dan pemeriksaan di pengadilan harus diupayakan diversi, dan juga SEJA RI Nomor : SE-002/J.A/1989 menyatakan Jaksa memiliki peluang untuk melakukan Diversi dalam menyelesaikan masalah ABH.Penelitian ini menggunakan metode penelitian yuridis normatif. Hasil Penelitian menyimpulkan bahwa SOP Diversi tingkat Penuntutan dirasa perlu dibentuk.
\end{abstract}

Kata Kunci: Diversi Di Tingkat Penuntutan, SOP Diversi Penuntutan

\section{A. PENDAHULUAN}

1. Latar Belakang

Undang-Undang Dasar Negara Republik Indonesia 1945, sebagai konstitusi negara Indonesia mengatur secara khusus mengenai perlindungan terhadap anak. Pasal 28 B Undang-Undang Dasar Negara Republik Indonesia Tahun 1945 menyatakan setiap anak berhak atas kelangsungan hidup, tumbuh, dan berkembang serta berhak atas perlindungan dari kekerasan dan diskriminasi.

Penanganan perkara anak berhadapan dengan hukum yang mengutamakan kepentingan terbaik bagi anak masih jauh dari yang diharapkan. Pemerintah telah mengeluarkan peraturan khusus yang mengatur perlindungan hak-hak

\footnotetext{
${ }^{1}$ Mahasiswa Program Studi Magister Ilmu Hukum UNDIP

${ }^{2}$ Dosen Program Studi Magister Ilmu Hukum UNDIP
} 
anak yang berhadapan dengan hukum, seperti Undang- Undang No.3 Tahun 1997 Tentang Pengadilan Anak, ataupun Undang-Undang No. 23 Tahun 2002 Tentang Perlindungan Anak bahkan pemerintah telah meratifikasi Konvensi Hak Anak (KHA) dengan mengeluarkan Keppres Nomor 36 Tanggal 25 Agustus 1990, dan menandatangani kesepakatan Beijing Rules, tapi ternyata ketentuan dalam peraturan tersebut bukan menjadi solusi terbaik penyelesaian perkara anak yang berhadapan dengan hukum.

Berikut data Tentang penyelesaian kasus anak yang berhadapan dengan hukum melalui jalur peradilan: ${ }^{3}$

1. Pengadilan Negeri Solo menangani kasus anak yang berhadapan dengan hukum berupa kasus pencurian sandal yang dilakukan oleh pelaku anak usia 15 Tahun dan anak usia 14 Tahun yang di sidang karena melakukan pemerasan terhadap teman sekolahnya. Mereka harus ditahan di Rutan Solo beberapa bulan.

2. Hasil Rekapitulasi Data Penanganan Perkara Anak Yang Berhadapan Dengan Hukum (ABH) di Wilayah hukum Kejaksaan Tinggi Jawa Tengah Tahun 2012 yang meliputi 36 Kejaksaan Negeri (Kejari) dan 1 Cabang Kejaksaan Negeri (Cabjari) di Pelabuhan terdapat 131 Kasus perkara yang melibatkan anak sebagai pelaku tindak pidana, dimana Pasal dan Kualifikasi Tindak Pidana yang dilakukan sangat beragam. ${ }^{4}$

Berdasarkan data penunjang diatas diketahui bahwa banyak anak yang bermasalah dengan hukum yang harus menjalani proses peradilan pidana. Di

\footnotetext{
3 Dian Sasmita, Anak-anak Dibalik Terali Besi, Serial Online Maret 22, 2011, http://Anak-anak-DibalikTerali.com, Hal. 1, diakses pada tanggal 12 Mei 2014.

4Data Anak Berkonflik dengan Hukum Tahun 2012 Kejaksaan Tinggi Jawa Tengah.
} 
usianya yang masih sangat muda, mereka harus mengalami proses hukum atas perkara pidana yang demikian panjang dan melelahkan, mulai dari tahap penyidikan oleh Penyidik Polisi, penuntutan oleh Jaksa Penuntut Umum, persidangan oleh Majelis Hakim dan pelaksanaan putusan hakim oleh Jaksa selaku Eksekutor Putusan.

United Nations Standard Minimum Rules for the Administration of Juvenile Justice ("The Beijing Rules") butir 6 dan 11 menyatakan: ${ }^{5}$

\section{Scope of Direction}

6.1 In view of the varying special needs of juveniles as well as the variety of measures available, appropriate scope for discretion shall be allowed at all stages of proceedings and at the different levels of juvenile justice administration, including investigation, prosecution, adjudication and the follow-up of dispositions. (Mengingat berbagai kebutuhan khusus remaja serta berbagai langkah-langkah yang tersedia, ruang lingkup yang tepat untuk diskresi harus diizinkan di semua tahap proses dan pada berbagai tingkat administrasi peradilan anak, termasuk penyidikan, penuntutan, putusan dan tindak lanjut disposisi)

\section{Diversion}

11.1Consideration shall be given, wherever appropriate, to dealing with juvenile offenders without resorting to formal trial by the competent authority, referred to in rule 14.1 below.

(Pertimbangan harus diberikan, sejauh memungkinkan, untuk menangani para pelaku anak tanpa ke pengadilan resmi oleh pejabat yang berwenang, sebagaimana dimaksud dalam aturan 14.1 di bawah ini)

11.2 The police, the prosecution or other agencies dealing with juvenile cases shall beempowered to dispose of such cases, at their discretion, without recourse to formal hearings, in accordance with the criteria laid down for that purpose in the respective legal system and also in accordance with the principles contained in these Rules.

(Polisi, Jaksa atau lembaga lain yang berhubungan dengan kasuskasus anak harus diberikan wewenang untuk menyelesaikan kasus tersebut, dengan diskresi mereka, tanpa bantuan sidang formal, sesuai dengan kriteria yang ditetapkan untuk tujuan itu dalam sistem hukum masing-masing dan juga sesuai dengan prinsip-prinsip yang terkandung dalam aturan ini)

${ }^{5}$ Butir 6 dan 11 The Beijing Rules 
Butir 6 dan 11 The Beijing Rules di atas terdapat pernyataan mengenai Diversi yakni sebagai proses pelimpahan anak yang berkonflik dengan hukum dari sistem peradilan pidana ke proses informal seperti mengembalikan kepada lembaga sosial masyarakat baik pemerintah atau non pemerintah.

Pertimbangan dilakukan Diversi yang harus dilakukan oleh setiap aparat penegak hukum baik di tingkat penyidikan, penuntutan, pemeriksaan pengadilan adalah filosofi sistem peradilan pidana anak untuk melindungi dan merehabilitasi (protection and rehabilitation) anak pelaku tindak pidana. ${ }^{6}$

Pengaturan mengenai Diversi terdapat dalam Pasal 6 sampai dengan Pasal 16 Undang-Undang Nomor 11 Tahun 2012.. Kewenangan untuk melakukan Diversi adalah dari aparat penegak hukum pada masing masing tingkatan pemeriksaan sebagaimana yang di muat dalam Pasal 7. Diversi dilakukan dengan musyawarah yang melibatkan pihak-pihak sebagaimana tercantum dalam Pasal 8.

Permasalahan yang diteliti adalah kebijakan Diversi dalam rangka perlindungan hukum bagi anak yang berkonflik dengan hukum menurut Undang - Undang Nomor 11 Tahun 2012 Tentang Sistem Peradilan Pidana Anak serta konsep Standar Operasional Prosedur (SOP) pelaksanaan Diversi di tingkat Penuntutan terhadap anak yang berkonflik dengan hukum.

\section{Metode Penelitian}

${ }^{6}$ Jack E Bynum, William E. Thompson. 2002. J uvenile Delinquency a Sociological Approach. Boston: Allyn and Bacon A Peason Education Company 
Metode yang digunakan dalam penulisan tesis ini ialah Metode Teknik pengumpulan data yang digunakan adalah dengan cara studi kepustakaan dan dokumen yang memusatkan pada data sekunder yang terdiri dari bahan hukum primer, sekunder, dan tersier. Metode analisis data yang digunakan adalah metode analisis kualitatif.

\section{Kerangka Teori}

a. Sistem Peradilan Pidana Anak

Undang-Undang Nomor 11 Tahun 2012 memberikan pengertian tentang Sistem Peradilan Pidana Anak: ${ }^{7}$

Sistem Peradilan Pidana Anak adalah keseluruhan proses penyelesaian perkara Anak yang berhadapan dengan hukum, mulai tahap penyelidikan sampai dengan tahap pembimbingan setelah menjalani pidana.

Peradilan anak bertujuan memberikan yang paling baik bagi anak, tanpa mengorbankan kepentingan masyarakat dan tegaknya keadilan. ${ }^{8}$ Peradilan anak diselenggarakan dengan tujuan untuk mendidik kembali dan memperbaiki sikap dan perilaku anak sehingga ia dapat meninggalkan perilaku buruk selama ini telah ia lakukan.

Peradilan anak meliputi segala aktivitas pemeriksaan dan pemutusan perkara yang menyangkut kepentingan anak. Ruang lingkup Peradilan Anak yaitu meliputi:

a. Segala aktifitas pemeriksaan

b. Pemutusan perkara

c. Hal-hal yang menyangkut kepentingan anak.

b. Tindak Pidana Anak

\footnotetext{
${ }^{7}$ Pasal 1 butir 1 Undang-Undang Nomor 11 Tahun 2012 Tentang Sistem Peradilan Pidana Anak. 8 Maidin Gultom, Perlindungan Terhadap Anak Dalam Sistem Peradilan Pidana Anak di Indonesia, (Refika Aditama, 2008), hal. 77.
} 
Istilah kenakalan anak diambil dari istilah asing Juvenile Deliquency. Deliquency adalah tindakan atau perbuatan (act) yang dilakukan oleh anak, dimana jika tindakan atau perbuatan itu dilakukan oleh orang dewasa merupakan suatu kejahatan. ${ }^{9}$

Delinquency juga berarti doing wrong, terabaikan/ mengabaikan yang kemudian diperluas artinya jahat, asosial, kriminal, pelanggar aturan, pembuat ribut, pengacau, penteror, tidak dapat diperbaiki lagi, durjana, dursila dan lain-lain. Dengan demikian secara etimologi Juvenille Deliquency adalah kejahatan anak, yang pelakunya adalah anak. ${ }^{10}$

Pengertian Juvenille Deliquency menurut Kartini Kartono adalah sebagai berikut: ${ }^{11}$

Juvenile Deliquency yaitu perilaku jahat / dursila, atau kejahatan / kenakalan anak-anak muda, merupakan gejala sakit (patologi) secara sosial pada anakanak dan remaja yang disebabkan oleh suatu bentuk pengabaian sosial sehingga mereka itu mengembangkan bentuk pengabaian tingkah laku yang menyimpang.

c. Restorative Justice dan Diversi

Keadilan Restoratif dapat diartikan sebagai penyelesaian perkara tindak pidana dengan melibatkan pelaku, korban, keluarga pelaku/korban dan pihak lain yang terkait untuk bersama-sama mencari penyelesaian yang adil dengan menekankan pemulihan kembali pada keadaan semula dan bukan pembalasan. Prinsip-prinsip dari keadilan restoratif adalah: ${ }^{12}$

1. Menekankan keadilan pada perbaikan/ pemulihan keadaan

\footnotetext{
${ }^{9}$ Setya Wahyudi, Op.cit., hal. 29.

${ }^{10}$ Ibid.

${ }^{11}$ Kartini Kartono, Patologi Sosial 2, Kenakalan Remaja,(Jakarta: PT Raja Grafindo Persada, 2003), hal.7

${ }^{12}$ http://lib.ui.ac.id/file?file=digital/20315231-T31921-Perdamian\%20dalam.pdf. $\quad$ Diakses pada tanggal 14 Juli 2014.
} 
2. Berorientasi pada korban

3. Memberikan kesempatan pada pelaku untuk mengungkapkan rasa sesalnya pada korban dan sekaligus bertanggung jawab.

4. Memberikan kesempatan kepada pelaku dan korban untuk bertemu untuk mengurangi permusuhan dan kebencian.

5. Mengembalikan keseimbangan dalam masyarakat

6. Melibatkan anggota masyarakat dalam upaya pemulihan.

Dengan penerapan Restorative Justice akan timbul pergeseran arah pemidanaan dan tujuan pemidanaan yang bersifat menghukum dan atau balas dendam dengan cara mempertanggungjawabkan setiap perbuatan yang dilakukan berganti menjadi suatu perbuatan yang lebih menekankan pada usaha untuk menyembuhkan dan merupakan suatu tindakan yang bersifat mensejahterakan antara pelaku, korban dan masyarakat. ${ }^{13}$

Diversi menurut Jack. E. Bynum adalah: ${ }^{14}$

"Diversion is an attempt to devert, or channel out, youthfull offenders from the juvenille justice system." (Diversi adalah sebuah tindakan atau perlakuan untuk mengalihkan atau menempatkan pelaku tindak pidana anak keluar dari sistem peradilan).

Pertimbangan dilakukan Diversi oleh pengadilan yaitu filosofi sistem peradilan pidana anak untuk melindungi dan merehabilitasi (protection and rehabilitation) anak pelaku tindak pidana. ${ }^{15}$

Berikut beberapa dasar hukum mengenai prinsip-prinsip perlindungan anak yang terkait ketentuan Diversi :

1.Peraturan Internasional

a. Convention on the Rights of The Child (Konvensi Hak-Hak Anak)

\footnotetext{
${ }^{13}$ Ibid.

${ }^{14}$ Jack E Bynum, William E. Thompson, Juvenile Delinquency a Sociological Approach. (Boston: Allyn and Bacon A Peason Education Company, 2002), hal. 430.

${ }^{15}$ Ibid, hal. 431.
} 
b. The United Nations Standard Minimum Rules for Administration of Juvenile Justice - the Beijing Rules (Peraturan Standar Minimum PBB untuk Pelaksanaan Peradilan Anak -Peraturan Beijing)

c. The United Nations Rules for the Protection of Juvenile Deprived of Their Liberty (Peraturan PBB untuk Perlindungan Anak yang Terampas Kebebasannya)

2. Peraturan Nasional

a) Undang-Undang No. 23 Tahun 2002 Tentang Perlindungan Anak

b) Undang-Undang No. 11 Tahun 2012 Tentang Sistem Peradilan Pidana Anak

c) Surat Edaran Jaksa Agung RI Nomor : SE-002/J.A/4/1989 Tentang Penuntutan Terhadap Anak

d) Surat Jaksa Agung Muda Tindak Pidana Umum B-532/E/11/1995, tentang Petunjuk Teknis Penuntutan Terhadap Anak

d. Pengertian Anak dan Batasan Usia Anak

Pasal 1 butir 1 Undang-Undang Nomor 3 Tahun 1997 Tentang Pengadilan Anak, pengertian anak adalah orang yang dalam perkara anak nakal telah mencapai umur 8 (delapan) tahun tetapi belum pernah kawin. Dikaitkan dengan putusan Mahkamah Konstitusi Nomor 1/PUUVIII/2010 Tanggal 24 Februari 2011, batas umur Anak Nakal yang dapat diajukan ke Sidang Anak adalah sekurang-kurangnya 12 (dua belas) tahun tetapi belum mencapai umur 18 (delapan belas) tahun dan belum pernah kawin. Apabila Si Anak melakukan tindak pidana pada batas umur 
sekurang-kurangnya 12 (dua belas) tahun tetapi belum mencapai umur 18 (delapan belas) tahun dan ketika diajukan ke sidang pengadilan anak yang bersangkutan melampaui batas 18 (delapan belas) tahun tetapi belum mencapai umur 21 (dua puluh satu) tahun, tetap diajukan ke Sidang Anak. Apabila anak belum mencapai umur 12 (dua belas) tahun melakukan atau diduga melakukan tindak pidana, maka terhadap anak tersebut dapat dilakukan pemeriksaan oleh Penyidik.

Undang - Undang SPPA memberikan pengertian anak yaitu Anak yang Berhadapan dengan Hukum adalah anak yang berkonflik dengan hukum, anak yang menjadi korban tindak pidana, dan anak yang menjadi saksi tindak pidana. ${ }^{16}$

Hendaknya putusan MK ini diikuti dengan merevisi peraturan perundang-undang tentang anak, seperti UU No.3/1997 tentang pengadilan anak yang masih mengatur usia 8 tahun sebagai usia pertanggungjawaban pidana anak.

e. SOP dan Penuntutan

Definisi Standar Operasional Prosedur (SOP) adalah pedoman atau acuan untuk melaksanakan tugas pekerjaan sesuai dengan fungsi dan alat penilaian kinerja instasi pemerintah berdasarkan indikator indikator teknis, administrasif dan prosedural sesuai dengan tata kerja, prosedur kerja dan sistem kerja pada unit kerja yang bersangkutan. ${ }^{17}$

Tindakan penuntutan meliputi pengertian - pengertian pelimpahan perkara ke Pengadilan, Pelaksanaan Pemeriksaan di Pengadilan, Upaya

\footnotetext{
${ }^{16}$ Pasal 1 butir 2 Undang-Undang Nomor 11 Tahun 2012 tentang Sistem Peradilan Pidana Anak ${ }^{17}$ http://armylookfashion.com/2011/12/15/pengertian-standar-operasional-prosedur-definisisop.html/. Diakses pada tanggal 15 Maret 2014 pukul 17.48 WIB.
} 
Hukum Biasa dan Luar Biasa sampai ada putusan Hakim di sidang pengadilan. $^{18}$

\section{B. PEMBAHASAN}

1. Kebijakan Diversi dalam rangka perlindungan hukum bagi anak yang berkonflik dengan hukum menurut Undang - Undang Nomor 11 Tahun 2012 Tentang Sistem Peradilan Pidana Anak.

Pasal 1 butir 7 Undang-Undang SPPA menyatakan:

"Diversi adalah pengalihan penyelesaian perkara Anak dari proses peradilan pidana ke proses di luar peradilan pidana"

Diversi didasarkan pada kenyataan bahwa proses peradilan pidana terhadap anak pelaku tindak pidana melalui sistem peradilan pidana lebih banyak menimbulkan keburukan daripada kebaikan. Pengadilan akan memberikan stigmatisasi anak atas tindakan yang dilakukannya seperti anak dianggap jahat, sehingga lebih baik untuk membawanya ke luar sistem peradilan pidana. Pertimbangan dilakukan Diversi oleh pengadilan yaitu filosofi sistem peradilan pidana anak untuk melindungi dan merehabilitasi (protection and rehabilitation) anak pelaku tindak pidana. ${ }^{19}$

Ketentuan diversi dalam UU SPPA secara khusus diatur dalam Pasal 6 sampai Pasal 16.

Pasal 6:

Diversi bertujuan :

a. Mencapai perdamaian antara korban dan anak;

b. Menyelesaikan perkara anak diluar proses peradilan;

c. Menghindarkan anak dari perampasan kemerdekaan;

${ }^{18}$ Ibid.

${ }^{19}$ Jack E Bynum, William E. Thompson, Loc.cit. 
d. Mendorong masyarakat untuk berpatisipasi; dan

e. Menanamkan rasa tanggung jawab kepada anak.

Kelima tujuan UU SPPA dalam Pasal 6 yaitu semata-mata mengutamakan pendekatan kesejahteraan bagi anak dan kepentingan terbaik bagi anak. Pasal 7 di atas menjelaskan beberapa kriteria tindak pidana yang melibatkan anak sebagai pelaku, yang harus diupayakan penyelesaiannya dengan pendekatan prinsip diversi adalah: ${ }^{20}$

1. Kategori tindak pidana yang diancam dengan sanksi pidana sampai dengan 1 (satu) tahun harus diprioritaskan untuk diterapkan diversi, tindak pidana yang diancam dengan sanksi pidana di atas 1 (satu) tahun sampai dengan 5 tahun dapat dipertimbangkan untuk melakukan diversi, semua kasus pencurian harus diupayakan penerapan diversi kecuali menyebabkan atau menimbulkan kerugian yang terkait dengan tubuh dan jiwa;

2. Memperhatikan usia pelaku, semakin muda usia pelaku, maka urgensi penerapan prinsip diversi semakin diperlukan;

3. Hasil penelitian dari BAPAS, bila ditemukan faktor pendorong anak terlibat dalam kasus pidana adalah faktor yang ada di luar kendali anak maka urgenitas penerapan prinsip diversi semakin diperlukan;

4. Kerugian yang ditimbulkan oleh tindak pidana anak, bila akibat yang ditimbulkan bersifat kebendaan dan tidak terkait dengan tubuh dan nyawa seseorang maka urgenisitas penerapan diversi semakin diperlukan;

5. Pasal 9 menyiratkan aparat penegak hukum adalah Penyidik, Penuntut Umum dan Hakim ketika mempertimbangkan apakah akan dilaksanakan 
diversi atau tidak, harus memperhatikan: kategori tindak pidana yang dilakukan oleh anak; umur anak; hasil penelitian kemasyarakatan dari Bapas; kerugian yang ditimbulkan atas perilaku anak; bagaimana tingkat perhatian dan pendapat masyarakat atas kasus tersebut; dan dukungan lingkungan keluarga dan masyarakat. Tidak semua kasus anak dapat dilakukan pendiversian, karena pelaksaan diversi harus terlebih dahulu mendapatkan persetujuan dari korban dan keluarganya serta kesediaan anak dan keluarganya.

Diversi dan Keadilan Restoratif menjadi dasar dari pembaharuan hukum dalam pelaksanaan sistem peradilan pidana anak, yang dapat dilihat di dalam Undang-undang Nomor 11 Tahun 2012 tentang Sistem Peradilan Pidana Anak, yang bertujuan untuk menghindari anak pelaku tindak pidana dari hukuman atau pemidanaan. Ketentuan diversi dan keadilan restoratif dalam pelaksanaannya melibatkan pihak ketiga di dalam penyelesaian masalah antara anak yang melakukan dan anak yang menjadi korban dalam tindak pidana tersebut, dengan melibatkan masing-masing keluarga mereka, serta pihakpihak lain, dengan tujuan proses penyelesaian perkara diusahakan agar anak pelaku tindak pidana jauh dari proses pemidanaan terhadap anak pelaku tindak pidana.

2. Konsep SOP Diversi di Tingkat Penuntutan

Hal-hal yang perlu diperhatikan untuk dapat diatur dalam SOP Diversi Penuntutan Anak Yang Berhadapan dengan Hukum, antara lain:
a. Ketentuan Umum
b. Azas dan Tujuan 
Standar Operasional Prosedur (SOP) Diversi di Tingkat Penuntutan berdasarkan azas :

1) Perlindungan

2) Keadilan

3) Non diskriminasi

4) Kepentingan terbaik bagi anak

c. Ruang Lingkup

Standar Operasional Prosedur (SOP) Diversi di tingkat penuntutan terhadap anak yang berhadapan dengan hukum ini berlaku untuk semua proses pemeriksaan di tingkat penuntutan yang dilakukan oleh Jaksa Penuntut Umum baik di tingkat Kejaksaan Agung, Kejaksaan Tinggi, Kejaksaan Negeri maupun di tingkat Cabang Kejaksaan Negeri

d. Pihak-pihak yang terlibat dalam proses diversi di tingkat penuntutan:

d. Prosedur Pelaksanaan Diversi di Tingkat Penuntutan

Keseluruhannya harus diatur dalam SOP agar jelas tahapan pelaksanaan diversi.

\section{PENUTUP}

\section{Kesimpulan}

a. Konsep Diversion yang dalam istilah bahasa Indonesia disebut Diversi atau pengalihan diwujudkan dengan diundangkannya Undang-Undang Nomor 11 Tahun 2012 tentang Sistem Peradilan Pidana Anak (SPPA) yang di dalamnya memuat ketentuan mengenai diversi bagi anak yang berhadapan dengan hukum di dalam Pasal 6 sampai Pasal 16. 
b. Pelaksanaan diversi di tingkat penuntutan saat ini belum ada pedoman atau acuannya. Pedoman dan acuan ini dikenal dengan sebutan Standar Operasional Prosedur (SOP), sehingga perlu dibentuk SOP tersebut yang mengutamakan kepentingan anak dalam pelaksanaan diversi berlandaskan prinsip Keadilan Restoratif.

Pentingnya SOP Diversi dalam Penuntutan terhadap Anak Pelaku Tindak Pidana yang diantaranya:

a. Bahwa diversi sebagai suatu upaya agar anak terhindar dari sanksi pidana akibat proses peradilan.

b. Bahwa ketentuan-ketentuan tata laksana Diversi dalam Penuntutan yang baku belum diatur.

c. Bahwa Undang-Undang Nomor 11 Tahun 2012 tentang Sistem Peradilan Pidana Anak Pasal 7 mengamanatkan bahwa di setiap proses penyidikan, penuntutan, dan pemeriksaan di pengadilan harus diupayakan diversi.

Bahwa Surat Edaran Jaksa Agung RI Nomor : SE-002/J.A/1989 Tentang Penuntutan Terhadap Anak menyatakan Jaksa memiliki peluang untuk menjalankan metode Diversi dalam menyelesaikan masalah anak yang berhadapan dengan hukum.

\section{SARAN}

1. Perlu diatur di dalam Peraturan perundang-undangan yang dapat dijadikan sebagai acuan pelaksanaan diversi secara teknis, mengenai tatacara pelaksanaan Diversi disetiap tingkatan, terutama di tingkat penuntutan. 
2. Agar segera di lakukan sosialisasi kepada masyarakat sehingga masyarakat mengerti akan adanya Diversi dalam penyelenggaraan sistem peradilan pidana.

3. Pemerintah perlu segera membentuk Lembaga-lembaga sesuai amanat Undang - Undang Nomor 11 Tahun 2012 Tentang SPPA untuk menangani program-program Diversi yang didukung oleh penegak hukum, pemerintah, organisasi sosial/LSM dan para pemerhati perlindungan anak sebagaimana telah disebutkan dalam Undang-Undang SPPA.

4. Perlu diatur mengenai pengawasan yang lebih ketat pelaksanaan Diversi dalam tiap tahapan dari Kepolisian, Kejaksaan dan Pengadilan agar tidak terjadi penyalahgunaan wewenang menyangkut Diversi.

5. Perlu dilakukan penelitian lebih lanjut akibat dari penerapan Diversi terhadap pelaku tindak pidana oleh anak.

\section{DAFTAR PUSTAKA}

\section{Literatur}

Abdussalam, 2007, Hukum Perlindungan Anak, Ratu Agung, Jakarta ,2007, Kriminolog, Ratu Agung, Jakarta

Chazawi, Adami, Pelajaran Hukum Pidana Bagian 1, Jakarta: Raja Grafindo Persada, 2001,

Dirdjosisworo, Soedjono, Ilmu Jiwa Kejahatan. Karya Nusantara, Bandung, 1977

Effendy, Marwan, Kejaksaan RI: Posisi dan Fungsinya dari Perspektif Hukum. Jakarta: PT. Gramedia Pustaka Utama, 2005 
E Bynum, Jack, William E. Thompson, Juvenile Delinquency a Sociological Approach. (Boston: Allyn and Bacon A Peason Education Company, 2002

Gultom,Maidin, Perlindungan Hukum Terhadap Anak, Refika Aditama, Bandung,2010

Gunarsa, Psikologi Remaja. Jakarta, Gunung Mulya, 1988

Hadi Suprapto, Paulus, Delinquency Anak Pemahaman dan Penanggulangannya,, Malang : Penerbit Selaras, 2010.

Kartono,Kartini, Patologi Sosial II, Kenakalan Remaja, Jakarta, Rajawali Pers,2008.

Muladi dan Barda Nawawi Arief, Teori-teori dan Kebijakan Pidana (cetakan ketiga), Bandung : Alumni, 2005.

Marlina, Peradilan pidana Anak di Indonesia "Pengembangan konsep Diversi danRestorative Justice" Bandung : Refika Aditama, 2009

Meliala, Syamsudin dan E. Sumaryono, Kejahatan Anak Suatu Tinjauan dari Psikologis dan Hukum, Liberty, Yogyakarta, 1985

Mulyadi, Lilik, Pengadilan Anak di Indonesia Teori, Praktik dan Permasalahannya. Bandung: Bandar Maju, 2005.

Wahyudi, Setya,Implememntasi Ide Diversi Dalam Pembaruan Sistem Peradilan Pidana Anak Indonesia, Yogyakarta: Genta Publishing, 2011.

Zulfa, Achzani, Keadilan Restoratif, Jakarta : Badan Penerbit FH UI, 2009 


\section{Peraturan Perundang-Undangan}

Convention on the Rights of The Child (Konvensi Hak-Hak Anak)

The United Nations Standard Minimum Rules for Administration of Juvenile Justice - the Beijing Rules (Peraturan Standar Minimum PBB untuk Pelaksanaan Peradilan Anak-Peraturan Beijing)

Undang-Undang Nomor 11 Tahun 2012 tentang Sistem Peradilan Pidana Anak Undang-Undang Nomor 16 Tahun 2004 Tentang Kejaksaan

Peraturan Jaksa Agung Republik Indonesia Nomor : PER-036 / A / JA / 09 / 2011 Tanggal 21 September 2011 Tentang Standar Operasional Prosedur (SOP) Penanganan Perkara Tindak Pidana Umum

\section{Website}

http://armylookfashion.com/2011/12/15/pengertian-standar-operasionalprosedur-definisi-sop.html/. Diakses pada tanggal 15 Maret 2014 pukul 17.48 WIB. 